\title{
ANALISIS SWOT UNTUK MENENTUKAN STRATEGI KOMPETITIF PADA PD. BPR. BANK DAERAH LAMONGAN
}

\author{
Mohamad Rizal Nur Irawan \\ Universitas Islam Lamongan \\ Email : rijal_peace@yahoo.co.id
}

\begin{abstract}
Abstrak
Berkaitan dengan meningkatnya persaingan Global,maka perusahaan dituntut untuk memperhatikan keadaan pasar dan bersaing lebih kompetitif dalam menentukan strategi.Strategi kompetitif merupakan salah satu cara untuk mengetahui daya saing disetiap kekuatan.Pengunaan analisis SWOT yang efektif dapat memegang peranan dalam menentukan strategi kompetitif,agar dapat mengetahui kekuatan, kelemahan, peluang dan ancaman yang dihadapi oleh perusaahaan dalam menjaga kelangsungan hidup perusahaan.Masalah yang hendak di cari jawabannya dalam penelitian ini adalah"apakah analisis SWOT merupakan strategi yang tepat guna meningkatkan produksi perushaan dan bagaimana strategi kompetitif yang di terapkan perusahaan dalam mengatasi persaingan global?". penelitian ini dilakukan dengan menggunakan metode analisis IFAS untuk menganalisis faktor internal,analisis EFAS untuk faktor eksternal. Setelah dimasukan kedalam model kuantittif yaitu matrik SWOT.Hasil analisis menunjukan bahwa, menggunakan analisis IFAS dan EFAS serta menggunakan analisis SWOT ,maka strategi yang dipilih guna tercapainya tujuan dari perusahaan adalah" strategi $S T$ ". Berdasarkan bukti tersebut dapat disimpulkan bahwa dengan analisis SWOT dapat mengatasi persaingan yang ditentukan dengan memakai strategi kompetitif yaitu, dengan strategi diversifikasi produk.
\end{abstract}

Kata kunci : Analisis SWOT, Strategi kompetitif

\begin{abstract}
The rising of global competition, the companies must considering the circumstances of market and more competitiveof determine strategy. Competitive strategy is a way to determine the power competitiveness. Use of an effective SWOT analysis for a role in determining the competitive strategy, in order to determine the strengths, weaknesses, opportunities and threats encountered by company to keep going company survive. The Problems which you want to find the answer in this study is "whether the SWOT analysis is an appropriate strategy in order to increase the production of Performance Management and how competitive strategies were implemented company in overcoming the global competition? This research using IFAs analysis method to analyze the internal factors, the analysis of EFAS to external factors. After inserted into quantitative model that is name SWOT. The Results of analysis showed that analysis of IFAS and EFAS and SWOT analysis, the strategy selected for the achievement goal of the company is "strategy ST". Based on this evidence we can conclude with the SWOT analysis be able to competition using a competitive strategy, with the strategy of product diversification.
\end{abstract}

Key word: SWOT analysis, competitive strategy 


\section{PENDAHULUAN}

Perubahan adalah suatu keadaan yang sangat sulit untuk diramalkan, diperkirakan dan dipastikan dimasa yang akan datang. Perusahaan tidak terlepas dari berbagai macam perubahan, yang bersumber dari lingkungan eksternal maupun lingkungan internal perusahaan. Perubahan yang berpengaruh negatif merupakan gangguan bagi perusahaan, sedangkan perubahan yang berpengaruh positif akan dapat menunjang kelangsungan hidup di perusahaan (Rangkuti 2006:4).

Seperti pembangunan di bidang ekonomi merupakan bagian dari pembangunan nasional, salah satu upaya untuk mewujudkan masyarakat adil dan makmur berdasarkan Pancasila dan Undang-undang Dasar 1945. Dalam rangka memelihara kesinambungan pembangunan tersebut, yang para pelakunya meliputi baik pemerintah maupun masyarakat sebagai orang perorangan dan hukum, sangat diperlukan dana dalam jumlah yang besar.

Pada jaman dahulu, sebelum adanya mata uang sebagai alat pembayaran, manusia dalam bertransaksi melakukan pembayaran dengan cara menukar barang yang akan dibeli atau diinginkan dengan barang yang dimiliki, yang kemudian disebut dengan barter. Namun seiring dengan perkembangan jaman, barter sendiri dirasakan kurang efisien karena setiap hari manusia harus membawa barang yang dimiliki, yang dapat ditukar guna berjaga-jaga apabila mereka ingin membeli barang di perjalanan. Oleh karena itu, manusia mulai berpikir untuk menciptakan suatu alat pembayaran yang sederhana dan ringkas, yang kemudian disebut dengan uang.

Perkembangan jaman yang semakin maju membuat uang tidak hanya sebagai alat pembayaran namun juga sebagai instrumen hutang, di mana apabila ada orang yang membutuhkan uang maka orang lain yang memiliki kelebihan uang dapat meminjamkan kepada mereka yang membutuhkan. Dalam kehidupan bermasyarakat, lambat laun dirasakan perlu adanya timbal balik dari peminjam kepada pemilik uang dalam proses peminjaman uang tersebut, yang kemudian dikenal dengan istilah bunga (interest) dalam masyarakat. Dasar pemahaman dari pemberian bunga atas pinjaman uang tersebut adalah karena uang tersebut dapat dikelola dan memberikan manfaat lebih kepada pemiliknya apabila tidak dipinjamkan kepada peminjam. Peminjaman uang tersebut kemudian menjadi menarik minat beberapa orang yang memiliki uang lebih untuk meminjamkan kepada orang yang membutuhkan. Timbul lah pertanyaan apabila ada orang yang 
memiliki uang lebih tetapi tidak banyak jumlahnya dan ingin meminjamkan uang tersebut kepada orang lain, serta adanya orang yang tidak memiliki uang namun ingin meminjamkan uang kepada orang lain. Hal ini lah yang mendorong tumbuhnya institusi perbankan.

Dalam Pasal 5 Undang-Undang Nomor 7 Tahun 1992 tentang Perbankan, disebutkan bahwa menurut jenisnya bank terdiri dari Bank Umum dan Bank Perkreditan Rakyat (BPR). Baik Bank Umum maupun BPR secara garis besar mempunyai fungsi yang sama dalam melaksanakan tugasnya yaitu menghimpun dan menyalurkan dana masyarakat, hal ini sesuai dengan fungsi utama perbankan Indonesia yang disebutkan dalam Pasal 3 Undang-Undang Nomor 7 Tahun 1992 tentang Perbankan.

PD. BPR. Bank Daerah Lamongan adalah merupakan salah satu perusahaan daerah yang bergerak dibidang perbankan. Pengembangan Bank Perkreditan Rakyat di Indonesia dimulai sejak setelah kemerdekaan. Pada waktu itu pemerintah mendorong pendirian bank-bank pasar yang tertutama sangat dikenal karena didirikan di lingkungan pasar dan bertujuan untuk memberikan pelayanan jasa keuangan kepada para pedagang pasar. Bank-bank tersebut kemudian berdasarkan Paket Oktober 1988, yang lebih dikenal dengan sebutan Pakto 1988, dikukuhkan menjadi Bank Perkreditan Rakyat.

Pada saat ini Bank Indonesia berharap agar Bank Perkreditan Rakyat mampu meningkatkan pelayanan kepada masyarakat, khususnya usaha mikro dan kecil. Hal tersebut bertujuan untuk memenuhi kebutuhan kredit atas masyarakat mikro dan kecil yang terkadang tidak dapat terjangkau oleh Bank Umum karena tidak terpenuhinya syarat-syarat perkeditan yang ditetapkan Bank Umum oleh masyarakat mikro dan kecil. Dengan adanya Bank Perkreditan Rakyat juga berfungsi supaya masyarakat mikro dan kecil tadi dalam memenuhi kebutuhan kreditnya tidak mengandalkan bantuan rentenir (lintah darat), mengingat bunga yang diberikan oleh rentenir pada umumnya sangat tinggi, sekitar $10 \%$ sampai dengan $20 \%$ setiap bulannya, sehingga dapat mengurangi banyaknya pertumbuhan rentenir. Peraturan perundang-undangan memberikan pengertian kredit sebagai penyediaan uang atau tagihan yang dapat dipersamakan dengan itu, berdasarkan persetujuan atau kesepakatan pinjam-meminjam antara bank dengan pihak lain yang mewajibkan pihak peminjam untuk melunasi utangnya setelah jangka waktu tertentu dengan pemberian bunga. 
Telah disadari, bahwa analisis faktor-faktor ekstern dan intern suatu perusahaan sangat mempengaruhi tercapainya suatu tujuan perusahaan, baik jangka pendek yaitu kemampuan untuk bertahan dan mengejar laba, maupun jangka panjang yaitu kelangsungan hidup usahanya. Faktor-faktor kekuatan, kelemahan, peluang, dan ancaman merupakan faktor yang dianalisis dalam SWOT ( Strength, Weakneses, Opportunities, Threat ) yang dapat menggambarkan kemampuan perusahaan yang optimal dan mengalokasikan dengan menggunakan sumber-sumber yang dimilikinya serta situasi yang dihadapi dalam usaha pencapaian suatu tujuan.

Berdasarkan latar belakang diatas, perumusan masalah yang penulis ambil dalam penelitian ini adalah : Apakah analisis SWOT dapat menentukan strategi kompetitif pada PD.BPR.Bank Daerah Lamongan,Apakah analisis SWOT dapat mengevaluasi faktor internal dan faktor eksternal pada PD.BPR.Bank Daerah Lamongan.

Tujuan dari penelitian ini sendiri adalah untuk mengetahui apakah analisis SWOT dapat menentukan strategi kompetitif pada PD.BPR.Bank Daerah Lamongan. Untuk mengetahui apakah dengan analisis SWOT dapat mengevaluasi faktor internal dan faktor eksternal pada PD. BPR. Bank Daerah Lamongan.

Dan diharapkan juga penelitian ini dapat memberikan kontribusi bagi beberapa pihak yang secara langsung bersinggungan dengan proses penulisan karya tulis ini antara lain untuk bagi peneliti yang bermanfaat untuk menambah ilmu pengetahuan, baik secara tertulis maupun secara praktis dan pengalaman utamanya mengenai penulisan penelitian, bagi perusahaan/usaha agar dapat digunakan sebagai bahan perencanaan dan pertimbangan bagi perusahaan/usaha dalam menentukan analisis SWOT untuk menentukan strategi kompetitif, bagi Universitas Islam Lamongan agar dapat bermanfaat sebagai bahan acuan dan tambahan informasi serta sebagai bahan referensi bagi penelitian sejenis selanjutnya Dan yang terakhir bagi pihak lain yang bermanfaat untuk menambah pengetahuan masyarakat tentang proses dan produk yang dimiliki perusahaan/bisnis dan faktor internal serta eksternal

Untuk dapat melakukan suatu pengadaan produk didalam perusahaan, tentunya diperlukan suatu pengertian terhadap beberapa istilah yang ada agar perusahaan dapat melakukan manajeman dengan baik. Mulyadi (2012:434) strategi adalah pola pengerahan seluruh sumber daya perusahaan untuk perwujudan visi melalui misi perusahaan. Richard L. Daft (2010:249) Mendenifisikan strategi (strategy) secara eksplit, yaitu rencana 
tindakan yang menerangkan tentang alokasi sumber daya serta berbagai aktivitas untuk menghadapi lingkungan, memperoleh keunggulan bersaing, dan mencapai tujuan perusahaan. Keunggulan bersaing (competitive advantage) adalah hal yang membedakan suatu perusahaan dari perusahaan lain dan memberi ciri khas bagi perusahaan untuk memenuhi kebutuhan pasar konsumen. Inti dari perumusan strategi adalah menentukan bagaimana perusahaan kita akan berbeda dengan perusahaan lain.

Rangkuti (2004:3) strategi adalah alat untuk mencapai tujuan. Sedangkan menurut Hamel dan Prahalad (1995:4) strategi adalah tindakan yang bersifat incremental (senantiasa meningkat) dan terus menerus dan dilakukan berdasarkan sudut pandang tentang apa yang diharapkan oleh para pelanggan di masa depan. Dengan demikian, perencanaan strategi hampir selalu dimulai dari “ apa yang dapat terjadi “, bukan dimulai dari " apa yang terjadi “. Terjadinya kecepatan inovasi pasar baru dan perubahan pola konsumen memerlukan kompetensi inti (core competencies). Perusahaan perlu mencari kompetensi inti didalam bisnis yang akan dilakukan.

Menurut Fredy Rangkuti (2004:18) menjelaskan bahwa analisis SWOT adalah identifikasi berbagai faktor secara sistematis untuk merumuskan strategi perusahaan. Analisis ini didasarkan pada logika yang dapat memaksimalkan kekuatan (strength) dan peluang (opportunities), namun secara bersamaan dapat meminimalkan kelemahan (weakneses) dan ancaman (threats). Proses pengambilan keputusan sinergi selalu berkaitan dengan pengembangan misi, tujuan, strategi dan kebijakan perusahaan. Dengan demikian perencanaan strategi harus menganalisa faktor-faktor strategi perusahaan (kekuatan, kelemahan, peluang, ancaman).

Menurut Wikipedia, analisis SWOT (singkatan dari bahasa inggris kekuatan/ strengths, kelemahan/ weakneses, kesempatan/ opportunities, dan ancaman/ threats) adalah metode perencanaan strategi yang digunakan untuk suatu spekulasi bisnis. Proses ini melibatkan penentuan tujuan yang spesifik dari spekulasi bisnis atau proyek dan mengidentifikasi faktor internal dan eksternal yang mendukung dan yang tidak dalam mencapai tujuan tersebut.

Menurut Ricard L. Daft (2010:253) Analisis SWOT (SWOT Analisis) yakni mencakup upaya-upaya untuk, mengenali kekuatan, kelemahan, peluang dan ancaman yang menentukan kinerja perusahaan. Informasi eksternal yang mengenai peluang dan ancaman dapat diperoleh dari banyak sumber, termasuk pelanggan, dan dokumen 
pemerintah, pemasok, kalangan perbankan, rekan perusahaan lain. Banyak perusahaan menggunakan jasa lembaga pemindaian untuk memperoleh kliping surat kabar, riset di internet dan analisis tren-tren domestik dan global yang relevan.

Didalam penelian ini terdapat unsur-unsur dari analisis SWOT yang terdiri dari : Unsur kekuatan (strength), yang dimaksud dengan kekuatan (strength) adalah semua potensi yang dimiliki perusahaan dalam mendukung proses pengembangan perusahaan, seperti kualitas sumber daya manusia, fasilitas-fasilitas perusahaan baik bagi SDM maupun bagi konsumen dan lain-lain.

Yang di maksud faktor-faktor kekuatan adalah antara lain kompetensi khusus yang terdapat dalam organisasi yang berakibat pada kepemilikan keunggulan komparatif oleh unit usaha dipasaran. Contoh : kekuatan pada sumber daya keuangan, citra positif, keunggulan kedudukan dipasar, dan kepercayaan bagi berbagai pihak yang berkepentingan atau yang berkaitan. Unsur yang kedua adalah kelemahan (Weakneses) yang dimana situasi dan kondisi yang merupakan kelemahan dari suatu perusahaan pada saat ini. Tepatnya terdapat kekurangan pada kondisi internal perusahaan, akibatnya kegiatan-kegiatan perusahaan belum bisa terlaksana secara maksimal. Misalnya: kekurangan dana, karyawan kurang kreatif dan malas, tidak adanya teknologi yang memadai dan sebagainya.

Unsur yang ketiga adalah peluang (Opportunities) yang dimaksud dengan peluang adalah faktor-faktor lingkungan luar atau eksternal yang positif, secara sederhana dapat diartikan sebagai setiap situasi lingkungan yang menguntungkan bagi suatu perusahaan atau satuan bisnis. yang dimaksud situasi lingkungan disini adalah :

a. Perubahan dalam kondisi pesaing,

b. Hubungan antara pembeli (konsumen),

c. Hubungan dengan pemasok yang harmonis,

d. Kecenderungan penting yang terjadi dikalangan pengguna produk,

e. Identifikasi suatu segmen pasar yang belum mendapat perhatian.

Dan yang terakhir adalah unsur ancaman (threat) yang dimaksudkan disini adalah dalam analisis SWOT yang bisa terjadi di lapangan adalah :

a. Harga bahan baku yang fluktuasif,

b. Masuknya pesaing baru di pasar,

c. Pertumbuhan pasar yang lambat, 
d. Pelanggan yang memiliki kepekaan terhadap harga dapat pindah ke pesaing yang menawarkan harga murah,

e. Pesaing yang memiliki kapasitas yang lebih besar dan daya jangkau yang luas. Dan unsur-unsur yang disebutkan diatas adalah unsur yang dicakup dari dalam lingkungan eksternal dan internal dalam suatu perusahaan.

Menurut Irham Fahmi (2013:260) untuk menganalisis secara lebih dalam tentang SWOT, maka perlu dilihat faktor faktor eksternal dan internal sebagai bagian penting dalam analisis SWOT, yaitu :

1. Faktor eksternal, faktor eksternal ini mempengaruhi terbentuknya Opportunities and Threat (O dan T). Dimana faktor ini menyangkut dengan kondisi-kondisi yang terjadi diluar perusahaan yang mempengaruhi dalam pembuataan keputusan perusahaan. Faktor ini mencangkup lingkungan industri dan lingkungan bisnis makro, ekonomi, politik, hukum, teknologi, kependudukan, dan sosial budaya.

2. Faktor internal, faktor internal ini mempengaruhi terbentuknya Strengths and Weakneses (S dan W). Dimana faktor ini menyangkut dengan kondisi-kondisi yang terjadi di dalam perusahaan yang mempengaruhi dalam pembuataan keputusan (decinion making) perusahaan. Faktor Internal ini meliputi semua macam manajemen fungsional :pemasar, keuangan, operasi, sumber daya manusia, penelitian dan pengembangan, sistem informasi manajemen dan budaya perusahaan (colporate culture)

Analisis SWOT membandingkan antara faktor eksternal peluang (Opportunities) dan ancaman (Threats) dengan faktor internal kekuatan (Streangths) dan kelemahan (Weaknesses). Faktor internal dimasukkan kedalam matrix yang disebut matrix faktor strategi eksternal EFAS (Eksternal Strategic Factor Analisis Summary). Setelah matrik faktor strategi eksternal dan internal selesai disusun, kemudian hasilnya dimasukkan dalam model kualitatif, yaitu matrik SWOT untuk merumuskan strategi pemasaran perusahaan adalah : a. Matrik Factor Strategi Eksternal (EFAS). Berikut ini adalah caracara penentuan faktor strategi eksternal (EFAS) : 1.Susunan dalam kolom 1 (5-10 peluang dan ancaman), 2.Beri bobot masing-masing faktor dalam kolom 2, mulai dari 1,0 (sangat penting) sampai dengan 0,0 (tidak penting). Faktor-faktor tersebut mungkin dapat memberikan dampak terhadap faktor strategi, 3.Hitung rating (dalam kolom 3) untuk masing - masing faktor dengan memberikan skala mulai dari 4 (out standing) sampai 
dengan 1 (poor) berdasarkan pengaruh faktor tersebut terhadap kondisi perusahaan yang bersangkutan. Pemberian nilai rating untuk faktor peluang bersifat positif (peluang yang semakin besar diberi rating +4 , tetapi jika peluang kecil diberi rating +1 ). Pemberian nilai rating ancaman adalah kebalikannya. Misalnya, jika nilai ancamannya sangat besar, ratingnya 1 . Sebaliknya, jika ancamannya nilai sedikit, maka ratingnya 4 , 4. Kalikan bobot pada kolom 2 dengan ranting kolom 3, untuk memperoleh faktor pembobotan untuk masing - masing faktor yang nilainya bervariasi mulai dari 4,0 (out standing) sampai dengan 1,0 (poor), 5.Gunakan kolom 5 untuk memberikan komentar atau catatan mengapa faktor - faktor tertentu dipilih dan bagaimana skor bobotnya dihitung, .Jumlah skor pembobotan (pada kolom 4), untuk memperoleh skor pembobotan bagi perusahaan yang bersangkutan. Nilai total ini menunjukkan bagaimana perusahaan tertentu bereaksi terhadap faktor - faktor strategis eksternalnya. Yang dapat dilihat pada tabel 2.3 EFAS, b.Matrik Factor Strategi Internal (IFAS) setelah faktor - faktor strategi internal suatu perusahaan diidentifikasi, suatu tabel IFAS disusun untuk merumuskan faktor - faktor strategi internal tersebut. Tahapannya adalah: 1.Tentukan faktor - faktor yang menjadi kekuatan serta kelemahan perusahaan pada kolom 1, 2.Beri bobot masimg - masing faktor tersebut dengan skala nilai 1,0 (paling penting) sampai 0,0 (tidak penting). Semua jumlah bobot tersebut jumlahnya tidak boleh melebihi skor total 1,00, 3. Hitung rating ( dalam kolom 3) untuk masing - masing faktor dengan memberikan skala mulai dari 4 (out standing) sampai dengan 1 (poor), berdasarkan dari pengaruh faktor tersebut terhadap kondisi perusahaan yang bersangkutan. Variable yang bersifat positif diberi nilai +1 sampai dengan membandingkannya dengan rata - rata industry atau dengan pesaing utama. Sedangkan, variable yang bersifat negative, sebaliknya. Contohnya, jika kelemahan perusahaan dibawah nilai rata - rata industry, nilai adalah 4, 4. Kalikan bobot pada kolom 2 dengan rating pada kolom 3, untuk memperoleh faktor pembobotan untuk masing - masing faktor yang nilainya bervariasi mulai dari 4,0 (out standing) sampai dengan 1,0 (poor), 5.Jumlah skor pembobotan pada kolom 4 untuk memperoleh total skor bagi perusahaan yang bersangkutan. Nilai total ini menunjukkan bagaimana perusahaan tetentu bereaksi terhadap faktor - faktor strategi internalnya. Yang dapat dilihat pada tabel 2.4 IFAS.

Alat yang dipakai untuk menyusun faktor - faktor strategis perusahaan adalah Matrik SWOT. Matrik ini dapat menggambarkan secara jelas bagaimana peluang dan 
ancaman ekternal yang dihadapi perusahaan dapat disesuaikan dengan kekuatan dan kelemahan yang dimilikinya. Matrik ini dapat menghasilkan 4 set kemungkinan alternative strategis. Keterangan untuk matrik tersebut adalah : 1.Strategi SO ini dibuat berdasarkan jalan pikiran perusahaan, yaitu dengan memanfaatkan seluruh kekuatan untuk merebut dan memanfaatkan peluang yang sebesar - besarnya. 2.Strategi ST adalah strategi dalam menggunakan kekuatan yang dimiliki perusahaan untuk mengatasi ancaman. 3.Strategi WO, strategi ini diterapkan berdasarkan pemanfaatan peluang yang ada dengan cara meminimalkan kelemahan yang ada. 4.Straetegi WT, strategi ini berdasarkan pada kegiatan yang bersifat defensive dan berusaha meminimalkan kelemahan yang ada serta menghindari ancaman.

Untuk strategi Kompetitif adalah pencapaian kompetitif yang diidamkan dalam industri, tempat dimana industri berada. Tujuan strategi kompetitif adalah mendapatkan keuntungan dan posisi yang mendukung dalam melawan kekuatan yang menentukan persaingan industri. Menurut Freddy Rangkuti (2006:153) keberhasilan suatu strategi yang telah ditetapkan sangat ditentukan oleh seberapa besar tingkat kesesuain strategi tersebut dengan perubahan lingkungan, pesaing, serta situasi organisasi faktor-faktor dalam merumuskan strategi : 1) Dalam kondisi persaingan yang kuat. 2) Membangun Kekuatan Kompetitif.

Untuk mengetahui daya saingnya disetiap kekuatan, Porter Michael E Porter menyarankan perusahaan untuk menggunakan salah satu dari tiga strategi yaitu diferensiasi, kepemimpinan biaya, atau fokus. Karakteristik perusahaan yang biasa dikaitkan dengan setiap strategi. Antara lain :

1. Strategi Diferensiasi, melibatkan upaya untuk membedakan produk atau layanan perusahaan dengan produk atau layanan perusahaan lain. perusahaan juga dapat menggunakan iklan yang kreatif, produk yang khas, pelayanan bermutu, teknologi baru untuk menghasilakan produk yang dianggap unik. Strategi diferensiasi juga dapat mengurangi persaingan jika pelanggan setia kepada merek perusahaan. Diferensiasi yang berhasil juga dapat mengurangi daya tawar pembeli karena produk lainnya dianggap kurang menarik, yang juga membantu perusahaan untuk mencegah ancaman produk pengganti. Serta mencegah munculnya pesaing baru.

2. Strategi Kepemimpinan Biaya. Dengan strategi ini, perusahaan berupaya keras untuk mencari fasilitas-fasilitas yang efesien, mengurangi biaya, dan mengotrol produksi 
dengan ketat agar lebih efisien dari pesaingnya. Jika perusahaan diposisi rendah biaya, berarti perusahaan dapat menetapkan harga lebih rendah dari pesaingnya, tetapi masih dapat menawarkan kualitas yang relative tinggi dan memperoleh keuntungan yang cukup banyak.Menjadi produsen biaya-rendah merupakan strategi yang baik untuk menghadapi lima kekuatan kompetitif. 3) Strategi Fokus. Dengan strategi ini, perusahaan berkonsentrasi untuk pasar wilayah atau kelompok pembeli tertentu. Perusahaan dapat menggunakan strategi diferensiasi atau kepemimpinan biaya, namun target pasar sempit.(Ricard L. Daft 263:2010).

Cara efektif untuk merumuskan strategi adalah lima kekuatan dan strategi kompetitif (Porter. Michael E Porter : 259) meneliti sejumlah perusahaan dan menyatakan bahwa strategi tingkat-usaha merupakan hasil dari lima kekuatan kompetitif dilingkungan perusahaan. Porter meneliti dampak internal terhadap strategi tingkat-usaha. Teknologi baru berbasis web berdampak positif maupun negative terhadap industri, dan memahami dampak tersebut sangat penting jika para manajer ingin menganalisa lingkungan kompetitif mereka secara akurat dan merumuskan tindakan strategi yang tepat adalah :

1. Potensi Pesaing Baru, Pada umumnnya, teknologi internet memudahkan perusahaan atau pengusaha baru untuk memasuki industri karena tidak memerlukan unsur unsur perusahaan seperti daya jual, asset fisik, maupun akses pemasok dan saluran penjualan.

2. Daya Tawar Pembeli, pelanggan yang cerdas menjadi pelanggan yang terberdayakan. Internet memungkinkan pelanggan untuk mengakses beragaman informasi mengenai kualitas, pemesanan, jasa dan pesaing, sehingga meningkatknt daya tawar mereka.

3. Daya tawar Pemasok, pemusatan pemasok dan ketersediaan pemasok pengganti merupakan faktor - faktor penting yeng menentukan daya tawar pemasok. Misalnya, internet memberikan akses kepada lebih banyak pelanggan bagi pemasok.

4. Ancaman Produk Pengganti, kekuatan alternative dan pengganti produk perusahaan dapat dipengaruhi oleh perubahan biaya, kualitas atau tren, misalnya peningkatan kesadaran pelanggan akan harga dan kualitas dapat melunturkan loyalitas pelanggan.

5. Pesaing Antar Kompetensi, pesaing antar kompetensi dipengaruhi oleh keempat faktor sebelumnya, disamping oleh biaya dan diferensiasi produk. Dengan 
meningkatnya kekuatan internet dan teknologi informasi, perusahaan dan para pengusaha makin sulit.

\section{METODE PENELITIAN}

Waktu yang digunakan untuk melaksanakan penelitian ini adalah pada bulan januari hingga bulan mei 2016. Sedangkan lokasi penelitian ini bertempat pada PD.BPR.Bank Daerah Lamongan yang beralamat di jalan Panglima Sudirman No.56 Kabupaten Lamongan Jawa Timur. Jenis penelitian kualitatif dengan pendekatan deskriptif yaitu sebuah penelitian yang bertujuan membuat pencandraan secara sistematis, faktual dan akurat mengenai fakta-fakta dan sifat-sifat objek penelitian (Sumandi Suryabrata).

Sugiono (29:2014) Statistik Deskriptis adalah statistik yang berfungsi untuk mendiskripsikan atau memberikan gambaran terhadap objek yang diteliti melalui data sampel atau populasi sebagaimana adanya, tanpa melakukan analisis dan membuat kesimpulan yang berlaku untuk umum.

Dalam penelitian ini adalah data yang ada Pada PD. BPR. Bank Daerah Lamongan. Dari uraian rencana penelitian diatas, teknik penarikan sampelnya adalah menggunakan populasi dan sampel yang terdiri dari data internal dan eksternal.

Adapun teknik dari penulis untuk pengambilan data ini menggunakan metode pendekatan tertentu untuk lebih mengarah ke penelitian. Dan dalam mengumpulkan data, dapat menggunakan teknik-teknik yang digunakan dalam pengumpulan data adalah : Observasi, wawancara, dokumentasi, Angkaet (Quisioner), studi pustaka.

Operasional Variabel adalah segala sesuatu yang berbentuk apa saja yang ditetapkan oleh peneliti untuk dipelajari sehingga diperoleh informasi tentang hal tersebut, kemudian ditarik kesimpulan. ( Sugiono 02:2014 ). Variabel disini ada dua(2) macam : 1. Variabel Independen/variabel bebas (X). Variabel ini sering disebut juga sebagai variabel stimulus, predictor, antecendent. Dalam bahasa Indonesia sering disebut variabel bebas. Variabel adalah merupakan variabel yang mempengaruhi atau yang menjadi sebab perubahannya atau timbulnya variabel dependen (terikat). Dalam SEM (Structural Equation Modeling) atau Pemodelan Persamaan Struktural, variabel independen disebut sebagai variabel eksogen. Dalam penelitian ini, yang termasuk dari variabel bebas adalah empat unsur penyusunan SWOT yang meliputi Strengths (kekuatan) sebagai $\left(\mathrm{X}_{1}\right)$, Weknesses 
(kelemahan) sebagai $\left(\mathrm{X}_{2}\right)$, Opportunies (peluang) sebagai $\left(\mathrm{X}_{3}\right)$, Threaths (ancaman) sebagai $\left(\mathrm{X}_{4}\right), 2$. Variabel Dependen/variabel terikat (Y). Variabel ini sering disebut juga sebagai variabel output, kriteria, konsekuen. Dalam bahasa Indonesia sering disebut variabel terikat. Variabel terikat adalah merupakan variabel yang dipengaruhi atau yang menjadi akibat, karena adanya variabel bebas. Dalam SEM (Structural Equation Modeling) atau Pemodelan Persamaan Struktural, variabel independen disebut sebagai variabel indogen.

Untuk dapat mengatasi masalah yang dihadapi, peneliti menggunakan teknik analisa dengan menggunakan teknik analisis SWOT, Matrik IFAS dan EFAS. Dengan metode ini dapat menunjukkan kinerja perusahaan dengan menentukan kombinasi faktor internal dan eksternal. Analisis SWOT membandingkan antara fokus internal yaitu, kekuatan (strength), dan kelemahan (weakness). Sedangkan faktor eksternal yaitu peluang (opportunity), dan ancaman (threats). Faktor internal dimasukan kedalam matrik yang disebut matrik faktor internal atau IFAS (Internal Strategic Factor Analysis Summary). Faktor eksternal dimasukan dalam matrik yang disebut matrik faktor eksternal atau EFAS (External Strategic Factor Analysis Summary). Setelah matrik faktor strategi internal dan eksternal selesai disusun kemudian hasilnya dimasukan kedalam model kualitatif yaitu matrik model SWOT untuk merumuskan strategi kompetitif perusahaan

\section{HASIL \& PEMBAHASAN}

Dari proses pengumpulan data yang telah dilakukan peneliti pada lokasi penelitian dan dari sumber-sumber lain yang relevan dengan menggunakan metode-metode pengumpulan data yang telah ditentukan sebelumnya didapatkan data-data yang diharapkan dapat menjawab permasalahan penelitian. 1. Kekuatan (strengths) PD. BPR. Bank Daerah Lamongan diantaranya : a) Dengan banyaknya nasabah atau calon nasabah dari berbagai daerah Ke PD.BPR.Bank Daerah Lamongan,maka sudah banyak pula orang yang mengenal PD.BPR.Bank Daerah Lamongan. b) PD.BPR.Bank Daerah Lamongan mempunyai pelayanan yang berkualitas, sehingga calon nasabah ataupun nasabah akan merasa terpuaskan. c) Kantor PD. BPR. Bank Daerah Lamongan terletak ditempat yang strategis. d) Komunikasi antara pimpinan PD.BPR.Bank Daerah Lamongan dengan para karyawan sangat baik, sehingga dapat melancarkan kegiatan atau aktivitas-aktivitas dalam bekerja. 2 . 
Kelemahan (weaknesses) PD. BPR. Bank Daerah Lamongan diantaranya : a) Kurangnya sarana dan prasarana di PD.BPR.Bank Daerah Lamongan, sehingga dapat menghambat perkembangan usaha. b) Pengembangan SDM belum mengarah keunggulan komperatif. c) Sebagaian besar kegiatan karyawan Di PD.BPR.Bank Daerah Lamongan masih dilakukan secara manual. d) Kurangnya riset dan pengembangan Di PD.BPR.Bank Daerah Lamongan, sehingga akan mempengaruhi pada pembaharuan jenis-jenis produk. 3. Peluang (opportunities) PD. BPR. Bank Daerah Lamongan diantaranya : a) Adanya pengenalan atau promosi dari internet,sehingga akan terjadi peningkatan calon nasabah yang dapat meningkatkan keuntungan Untuk PD.BPR.Bank Daerah Lamongan. b) Dengan jumlah penduduk yang semakin meningkat (factor Demografi) maka akan berdampak positif terhadap perkembangan usaha Pada PD.BPR.Bank Daerah Lamongan. c) Dengan banyaknya masyarakat yang mulai usaha perdagangan,maka peluang untuk memperoleh keuntungan akan lebih banyak. d) Mempunyai karyawan-karyawan yang bisa diandalkan kemampuannya, sehingga dapat ikut berpartisipasi dalam kemajuan PD.BPR.Bank Daerah Lamongan. 4. Ancaman (threaths) PD. BPR. Bank Daerah Lamongan diantaranya juga sebagai berikut : a) Dengan adanya perusahaan-perusahaan bank yang baru, akan menjadi pesaing bagi PD.BPR.Bank Daerah Lamongan. b) Adanya produk jasa bank pesaing yang lebih menarik daripada yang ada Di PD.BPR.Bank Daerah Lamongan,hingga dapat menjadi ancaman bagi kelangsungan usaha. c) Dengan adanya Perusahaan bank yang memiliki kapasitas dan fasilitas yang lebih memadai daripada PD.BPR.Bank Daerah Lamongan. d) Dengan adanya teknologi yang canggih menuntut PD.BPR.Bank Daerah Lamongan untuk mengeluarkan biaya operasional yang tinggi. Hal tersebut dapat dilihat pada tabel 5.1 faktor kekuatan PD.BPR.Bank Daerah Lamongan dan pada tabel 5.2 faktor kelemahan PD.BPR.Bank Daerah Lamongan. Sedangkan Untuk faktor peluang dapat dilihat pada tabel 5.6 dan tabel 5.7 untuk faktor ancaman.(Sumber:data primer diolah)

Dan setelah diketahui jumlah faktor kekuatan, kelemahan, peluang, dan ancaman, kemudian menentukan rating pada masing-masing faktor, yaitu faktor kekuatan, kelemahan, peluang, dan ancaman. Penentuan rating dapat dilihat pada tabel 5.3 untuk faktor kekuatan, tabel 5.4 untuk faktor kelemahan, tabel 5.8 untuk faktor peluang, dan tabel 5.9 untuk faktor ancaman(Sumber:data primer diolah). Dari tabel pembobotan tersebut dapat dihitung dengan rumus sebagai berikut : 


$$
\begin{aligned}
& \mathbf{a}=\frac{\mathbf{Y}_{\mathbf{1}}-\mathbf{Y}_{\mathbf{2}}}{\mathbf{X}_{\mathbf{1}}-\mathbf{X}_{\mathbf{2}}} \\
& \mathrm{b}=\mathrm{Y}_{1}-\mathrm{a} \cdot \mathrm{X}_{1} \text { atau } \mathrm{b}=\mathrm{Y}_{2}-\mathrm{a} \cdot \mathrm{X}_{2} \\
& \mathrm{X}_{1}=\text { Nilai aktual terendah } \\
& \mathrm{X}_{2}=\text { Nilai aktual tertinggi } \\
& \mathrm{X}=\text { Nilai rata-rata } \\
& \mathrm{Y}=\text { a.X }+\mathrm{b} \\
& \mathrm{Y}=\text { Rating } \\
& \mathrm{Y}_{1}=\text { Nilai skor terendah } \\
& \mathrm{Y}_{2}=\text { Nilai skor tertinggi }
\end{aligned}
$$

Setelah Pembobotan, dapat dilanjut dengan Matrik pembobotan, rating dan skor untuk faktor internal dan eksternal, yang dapat dilihat pada tabel 5.5 untuk internal dan 5.10 untuk eksternal.

Berdasarkan hasil analisis dengan menggunakan matriks SWOT dari beberapa faktor internal, berupa kekuatan dan kelemahan, serta faktor eksternal berupa peluang dan ancaman untuk menentukan strategi kompetitif bagi PD. BPR. Bank Daerah Lamongan adalah dengan melakukan strategi diversifikasi (produk, pasar), yaitu :a) Strategi SO yang mencangkup meningkatkan kinerja karyawan disertai dengan pengenalan lewat internet secara menarik,agar dapat menarik calon - calon nasabah baru, meningkatkan kualitas pelayanan dengan cepat dan efisien karena kemungkinan besar akan bertambahnya calon nasabah baru, meningkatkan komunikasi agar kegiatan dalam bekerja sehingga dapat kemajuan PD. BPR. Bank Daerah Lamongan. b) Strategi ST yang mencangkup dengan menambahkan produk-produk yang baru untuk menarik calon nasabah, memaksimalkan kapasitas dan fasilitas yang ada untuk meningkatkan loyalitas pada nasabah. c) Strategi WO yang mencangkup melakukan kegiatan yang dapat meningkatkan kualitas SDM (pelatihan atau seminar) hingga mengembangkan SDM yang kompetitif, melakukan riset dan pengembangan untuk menambah jenis produk agar dapat meningkatkan laba, pembaharuan sarana dan prasarana yang akan berdampak positif pada perkembangan usaha. d) Strategi WT yang mencangkup memaksimalkan teknologi yang untuk kelancara kegiatan karyawan agar lebih mudah dan efisien, meningkatkan kualitas SDM agar dapt mengembangkan kualitas perusahaan, dengan menambahkan perlengkapan peralatan 
yang kurang, agar dapat meningkatkan kapasitas dan fasilitas yang ada di perusahaan. Dan dapat dilihat pada tabel 5.11 matrik SWOT Untuk PD.BPR. Bank Daerah Lamongan. (Sumber:data primer diolah).

\section{SIMPULAN DAN SARAN}

\section{Simpulan}

Berdasarkan hasil penelitian dan uaraian pada pembahasan diatas, dapat di tarik kesimpulan dari penelitian ini adalah : Dari hasil analisis internal dan eksternal SWOT PD. BPR. Bank Daerah Lamongan untuk memperoleh strategi kompetitif dapat diambil kesimpulan sebagai berikut : a) Strategi SO yang mencangkup meningkatkan kinerja karyawan disertai dengan pengenalan lewat internet secara menarik,agar dapat menarik calon - calon nasabah baru, meningkatkan kualitas pelayanan dengan cepat dan efisien karena kemungkinan besar akan bertambahnya calon nasabah baru, meningkatkan komunikasi agar kegiatan dalam bekerja sehingga dapat kemajuan PD. BPR. Bank Daerah Lamongan. b) Strategi ST yang mencangkup dengan menambahkan produkproduk yang baru untuk menarik calon nasabah, memaksimalkan kapasitas dan fasilitas yang ada untuk meningkatkan loyalitas pada nasabah. c) Strategi WO yang mencangkup melakukan kegiatan yang dapat meningkatkan kualitas SDM (pelatihan atau seminar) hingga mengembangkan SDM yang kompetitif, melakukan riset dan pengembangan untuk menambah jenis produk agar dapat meningkatkan laba, pembaharuan sarana dan prasarana yang akan berdampak positif pada perkembangan usaha. d) Strategi WT yang mencangkup memaksimalkan teknologi yang untuk kelancara kegiatan karyawan agar lebih mudah dan efisien, meningkatkan kualitas SDM agar dapt mengembangkan kualitas perusahaan, dengan menambahkan perlengkapan peralatan yang kurang, agar dapat meningkatkan kapasitas dan fasilitas yang ada di perusahaan.

Dan untuk analisis SWOT sendiri dapat disimpulkan setelah mengidentifikasi apa yang ada pada PD. BPR. Bank Daerah Lamongan dengan menggunakan analisis SWOT, yaitu IFAS, EFAS dan matrik SWOT. Maka disimpulkan bahwa PD. BPR. Bank Daerah Lamongan mempunyai posisi yang sangat strategi untuk mendukung perkembangan memperoleh keunggulan strategi, PD. BPR. Bank Daerah Lamongan terletak pada kuadrat 1 , artinya pada pada posisi ini produk suatu perusahaan sangat mendukung untuk dilakukan strategi pertumbuhan agretif untuk mendapatkan keunggulan perusahaan agar 
dapat bersaing dengan perusahaan-perusahaan lain. Salah satu cara strategi yang dapat dilakukan adalah menciptakan ciri atau pembeda dari perusahaan-perusahaan lain strategi S-T.

\section{Saran}

Setelah penulis mempelajari keadaan yang terjadi pada perusahaan, dan berdasarkan kesimpulan diatas penulis disini juga menyarankan agar perusahaan PD. BPR. Bank Daerah Lamongan memperhatikan hal-hal sebagai berikut : Untuk faktor kekuatan (Strengths) perusahaan harus tetap menjaga dan mempertahankan pelayanan yang berkualitas yang diberikan perusahaan kepada nasabah maupun calon nasabah, agar tidak mempengaruhi minat nasabah serta loyalitas mereka. Untuk faktor kelemahan (Weknesses) perusahaan sebaiknya melakukan riset dan mengembangkan jenis produk yaitu dengan memaksimalkan produk yang ada dan menambah dengan produk - produk yang baru yang dapat menguntungkan (laba) bagi pihak perusahaan dan bagi masyarakat.

Untuk faktor peluang (Opportunity) perusahaan harus pandai dalam mengambil peluang atau kesempatan pemilihan strategi terbaik yang dapat diterapkan oleh perusahaan yaitu dengan strategi kompetitif yakni menggunakan kekuatan-kekuatan yang dimiliki PD. BPR. Bank Daerah Lamongan untuk memanfaatkan peluang jangka panjang. Dan yang terakhir adalah untuk faktor ancaman (Threath) perusahaan harus lebih meningkatkan kualitas dan daya jangkau yang luas agar dapat bersaing dengan perusahaan lain serta terhindar dari ancaman-ancaman perusahaan lain yang semakin bermunculan.

\section{DAFTAR PUSTAKA}

Akiyah,(2011), Analisis SWOT untuk menentukan Strategi Pemasaran dalam mengatasi

Persaingan pada UD. Lestari Jaya Meubel Tritunggal Babat Lamongan, Skripsi, Unisla, Lamongan

Anis Suci Fitriana,(2012), Analisa SWOT untuk menentukan Strategi Pengembangan Tabungan Simpanan Pada PD. BPR Bank Daerah Lamongan ,Skripsi, Unisla, Lamongan

Freddy Rangkuti,(2004), Analisis SWOT Teknik Membedah Kasus Bisnis, PT. Graedia, Jakarta 
Hamel dan Prahalad,(1995:4) dalam Freddy Rangkuti,(2004),"Analisis SWOT Teknik Membedah Kasus Bisnis”. PT. Graedia ,Jakarta.

Irham Fahmi,(2014), “Manajemen Strategis” ALFABETA Bandung.

Judin Mahfud, 2014. Skripsi Analisis SWOT unruk menentukan strategi kompetitif pada UD.DAMAI 4 GRESIK: Unisla.

Ismail Sholihin,(2006), Manajemen Strategik.

Mulyadi, (2012), Manajemen Stategi.

Porter Michael E. Porter dalam Freddy Rangkuti,(2006), “Analisis SWOT Membedah Kasus Bisnis", PT. Graedia, Jakart

Richard L. Daft,(2010), "Era Baru Manajemen,Edward Tanujaya”, Edisi 9, Salemba Empat.

Riduwan,Ds. M.BA,(2012), “Dasar-dasar Statistika”. ALFABETA, Bandung.

Rizal Awalodin Rozak. 2015. Skripsi Analisis SWOT Untuk Menentukan Strategi Pengembangan Jumlah Nasabah Kredit Moda Kerja (KMK)Pada PD. BPR BANK DAERAH LAMONGANI: Unisla

S. Nasution, Prof, Dr, M.A,(2012), “METODE RESEARCH”. BUMI AKSARA, Jakarta.

Sugiyono,(2014), “Statistika Untuk Penelitian”. ALFABETA, Bandung.

Sir Wahyuni Hidayawati. 2014. Skripsi Strategi Pemasaran Dengan Metode Analisa SWOT untuk Meningkatkan Penjualan Pada PT. INDOMARCO PRISMATAMA Benjeng Gresik: Unisla

http // analisisSWOT.Wikipedia.

http // infoindonesiaprintmedia.

http//manajemen/bisnis.strategi.gading mahendrata.

www.ruplubika.com.

www.humas.depkeu.go.id 